\title{
Perancangan Dan Pembuatan Aplikasi Permainan Edukasi Berhitung Dengan Binatang Menggunakan Metode Prototyping
}

\author{
Reza Novaris Maulana \\ Program Studi Sistem Informasi \\ Institut Informatika Indonesia \\ rezanovaris64@gmail.com
}

\author{
Raymond Sutjiadi \\ Program Studi Teknik Informatika \\ Institut Informatika Indonesia \\ raymond@ikado.ac.id
}

\author{
Edwin Meinardi Trianto \\ Program Studi Manajemen \\ Informatika \\ Institut Informatika Indonesia \\ edwin@ikado.ac.id
}

\begin{abstract}
Abstrak - Permainan edukasi merupakan suatu terobosan dimana permainan tersebut bersifat menghibur dan mengandung pengetahuan bagi penggunanya sehingga permainan ini diminati oleh banyak orang khususnya anak-anak. Dalam penelitian ini dibuat permainan edukasi dalam bentuk aplikasi Android yang diberi nama "Berhitung Dengan Binatang”. Permainan ini bertujuan untuk membangkitkan minat anak-anak akan pelajaran Matematika sekaligus mengenalkan berbagai macam jenis hewan. Aplikasi ini dibuat dengan menggunakan program aplikasi Unity dan metode pengembangan perangkat lunak throw-away prototyping. Untuk pengujian aplikasi ini, telah digunakan dua macam metode usability testing yaitu evaluating navigation and information architecture dan comparing products. Dari hasil pengujian evaluating navigation and information architecture didapatkan hasil $82 \%$ responden telah memahami fitur dan fungsi dari tombol yang telah disediakan pada aplikasi "Berhitung Dengan Binatang". Kemudian dari pengujian comparing products didapatkan hasil $73 \%$ responden tertarik untuk menggunakan aplikasi "Berhitung Dengan Binatang" sebagai media pembelajaran.

Kata Kunci: Android, Berhitung Dengan Binatang, Ilmu Pengetahuan Alam, Matematika, Permainan Edukasi, Unity, Usability Testing.
\end{abstract}

\section{PENDAHULUAN}

Pendidikan di Indonesia mempunyai program wajib belajar minimal 9 tahun dan wajib belajar 12 tahun [1]. Program ini mencakup pendidikan Sekolah Dasar (SD), Sekolah Menengah Pertama (SMP), dan Sekolah Menengah Atas (SMA). Pada tingkat Sekolah Dasar terdapat mata pelajaran pokok seperti Bahasa Indonesia, Agama, dan Pendidikan Kewarganegaraan (PKN). Selain itu terdapat mata pelajaran umum lain seperti Matematika, Kesenian, Ilmu Pengetahuan Alam (IPA), dan Ilmu Pengetahuan Sosial (IPS).
Metode pembelajaran untuk mata pelajaran Matematika pada awal pengenalannya masih menggunakan cerita bergambar dan metode tersebut dianggap efektif bagi siswa. Tetapi, kebanyakan para siswa yang baru pertama kali mengetahui metode tersebut membuat para siswa tidak tertarik karena siswa diminta untuk membaca soal sambil berhitung dan hal tersebut berdampak kurang tertariknya para siswa pada pelajaran Matematika khususnya dalam hal berhitung.

Selain mata pelajaran Matematika, pelajaran IPA dalam hal pengenalan hewan, awal pengenalannya masih menggunakan buku bergambar dan metode tersebut dianggap cukup menarik bagi siswa. Tetapi, kebanyakan dari para siswa yang baru pertama kali mengetahui tentang hewan hanya dikenalkan sebatas gambar dan nama hewan, sehingga metode tersebut dianggap kurang informatif bagi pembelajaran para siswa.

Dengan latar belakang tersebut, maka penelitian ini berupaya mendalami pembuatan aplikasi media pembelajaran untuk siswa, tentang pembelajaran Matematika dan pengenalan hewan, menggunakan teknologi Unity yang dipresentasikan melalui mobile device.

\section{METODOLOGI PENELITIAN}

\section{A. Game Edukasi}

Game berasal dari bahasa Inggris yang berarti permainan. Game adalah sebentuk karya seni dimana peserta, yang disebut pemain, membuat keputusan untuk mengelola sumber daya yang dimilikinya melalui objek yang ada di dalam game demi mencapai tujuan. Wendy Leigh Rountree mendefinisikan game sebagai suatu aktivitas yang membantu anak mencapai perkembangan yang utuh, baik fisik, intelektual, sosial, moral, dan emosional [2]. Berdasarkan uraian di atas maka dapat disimpulkan bahwa game adalah sebuah aktivitas yang dilakukan satu atau lebih pemain dengan aturan tertentu sehingga ada yang menang dan kalah dengan tujuan bersenang-senang, mengisi waktu luang. Game dimainkan terutama untuk hiburan, kesenangan, tetapi dapat juga berfungsi sebagai sarana latihan, pendidikan, dan simulasi. Game dapat mengasah kecerdasan dan keterampilan 
otak dalam mengatasi konflik atau permasalahan buatan yang ada dalam permainan.

\section{B. Unity}

Unity adalah perangkat lunak pembuat game 3D. Fitur Unity telah cukup efektif jika dibanding dengan memakai program framework. Program framework membuat para pengembang game memulai dari awal untuk membuat sistem-sistem yang digunakan pada game, terutama game 3D yang mempunyai sistem framework yang kompleks. Perangkat lunak framework ini mempunyai kelebihan untuk menjalankan game ke semua platform. Tetapi, dengan menggunakan Unity3D pun dapat membuat game ke cukup banyak platform game, antara lain: PC, Android, IOS, Flash, PS3, Xbox, Wii U, Blackberry 10, Windows Phone dan Web Player.

\section{Matematika}

Matematika adalah ilmu tentang bilangan, hubungan antar bilangan, dan prosedur operasional yang digunakan untuk menyelesaikan masalah mengenai bilangan dengan objek abstrak yang diatur secara logis, yang didapat melalui aktivitas berpikir [3]. Matematika merupakan wahana untuk mengembangkan karakter peserta didik yang positif dan bertujuan untuk membantu meningkatkan kemampuan matematis mereka dengan menggunakan penalaran dan logika untuk memecahkan masalah. Selain itu belajar Matematika bermanfaat dalam kehidupan yaitu menumbuhkan rasa ingin tahu yang sangat tinggi serta mempunyai sikap yang ulet serta percaya diri dalam menyelesaikan berbagai macam permasalahan.

\section{Ilmu Pengetahuan Alam (IPA)}

Ilmu Pengetahuan Alam (IPA) merupakan kumpulan pengetahuan yang diperoleh tidak hanya produk saja tetapi juga mencakup pengetahuan, seperti keterampilan dalam hal melaksanakan penyelidikan ilmiah [4]. Proses ilmiah yang dimaksud misalnya melalui pengamatan, eksperimen, dan analisis yang bersifat rasional. Sedangkan sikap ilmiah misalnya objektif dan jujur dalam mengumpulkan data yang diperoleh. Dengan menggunakan proses dan sikap ilmiah itu, saintis memperoleh penemuan-penemuan atau produk yang berupa fakta, konsep, prinsip, dan teori.

\section{E. Android}

Android adalah software untuk perangkat mobile yang mencakup sistem operasi, middleware, dan aplikasi kunci. Pengembangan aplikasi pada platform Android menggunakan bahasa pemrograman Java [5]. Serangkaian aplikasi inti Android antara lain klien email, program SMS, kalender, peta, browser, kontak, dan lain-lain. Dengan menyediakan sebuah platform pengembangan yang terbuka, pengembangan Android menawarkan kemampuan untuk membangun aplikasi yang sangat kaya dan inovatif. Pengembang bebas untuk mengambil keuntungan dari perangkat keras, akses informasi lokasi, menjalankan background services, mengatur alarm, tambahkan pemberitahuan ke status bar, dan masih banyak lagi.
Android bergantung pada versi Linux 2.6 untuk layanan sistem inti seperti keamanan, manajemen memori, manajemen proses, network stack, dan model driver. Kernel juga bertindak sebagai lapisan abstraksi antara hardware dan seluruh software stack.

\section{HASIL PEMBAHASAN}

\section{A. Analisis Permasalahan}

Berdasarkan latar belakang masalah pada penelitian ini bahwa mata pelajaran Matematika dan Ilmu Pengetahuan Alam (IPA) merupakan mata pelajaran yang sangat membutuhkan perhatian yang lebih dalam, khususnya bagi siswa yang baru mengetahui pelajaran tersebut. Para siswa membutuhkan media yang dapat membuat para siswa tertarik dalam hal belajar berhitung dan mengenalkan macam-macam hewan sehingga siswa akan lebih tertarik belajar tentang Matematika dan Ilmu Pengetahuan Alam.

Salah satu media yang digunakan dalam pelajaran adalah game atau permainan yang merupakan sarana pendidikan dan umumnya bisa disebut juga dengan permainan edukasi. Adanya karakteristik dari sebuah game yang menyenangkan dan menarik membuat aktivitas ini digemari banyak orang, khususnya anak-anak sehingga adanya permainan edukasi ini menjadi media edukasi yang menarik.

Permainan edukasi merupakan gabungan dari konten edukasi, prinsip belajar dan bermain yang bersifat menghibur serta mengandung banyak pengetahuan. Adanya permainan edukasi di sekolah menjadi terobosan yang sangat membantu dalam meningkatkan minat belajar di kalangan anak-anak sehingga dengan aplikasi permainan edukasi "Berhitung Dengan Binatang" menggunakan metode throw-away prototyping ini bisa membuat para siswa tertarik untuk belajar berhitung sekaligus memberikan pengetahuan tentang pengenalan macam-macam hewan.

\section{B. Desain Sistem}

Dalam pembuatan sebuah aplikasi diperlukan perancangan permainan "Berhitung dengan Binatang" dengan menggunakan beberapa diagram agar dapat menjelaskan alur kerja pada aplikasi yang dibuat. Use case diagram merupakan diagram yang menjelaskan tentang kegiatan yang dilakukan oleh aktor dan sistem untuk mencapai tujuan dan activity diagram merupakan diagram yang menggambarkan tentang aktivitas aktor pada sistem dari awal sampai akhir sehingga activity diagram menunjukan langkah-langkah proses kerja sistem yang dibuat.

\section{Use Case Diagram}

Use case diagram adalah salah satu pemodelan sistem yang menggunakan konsep berorientasi objek. Use case diagram dapat mendeskripsikan fungsionalitas sistem yang seharusnya dilakukan sesuai yang diinginkan oleh aktor eksternal atau aktor yang berinteraksi dengan sistem. Setiap use case dilengkapi dengan skenario, yaitu alur jalannya 
proses use case dari sisi aktor dan sistem. Gambar 1 adalah use case diagram pada aplikasi ini.

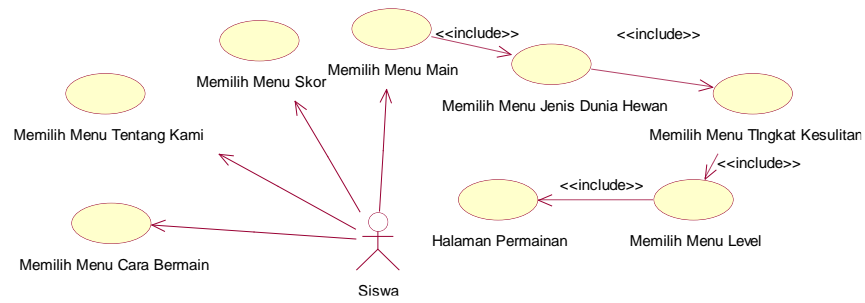

Gambar 1. Use Case Diagram Berhitung Dengan Binatang.

Use case diagram aplikasi "Berhitung dengan Binatang" memberikan gambaran singkat mengenai apa saja yang dilakukan oleh pengguna atau siswa ketika menjalankan aplikasi. Ketika pengguna masuk ke halaman utama aplikasi, pengguna dapat memilih menu mulai atau tentang cara bermain.

Saat memilih menu mulai, aplikasi akan menampilkan menu jenis dunia hewan dan awalnya hanya dunia darat yang disediakan. Setelah masuk ke menu jenis hewan darat, aplikasi menampikan menu tingkat kesulitan yang disediakan sehingga pengguna dapat memilih tingkat kesulitan dalam memainkan aplikasi. Kemudian di dalam menu tingkat kesulitan yang disediakan, terdapat menu level yang disediakan dan setelah masuk ke menu level, sistem menampilkan halaman permainan yang bisa dimainkan oleh pengguna yaitu siswa.

\section{Activity Diagram}

Activity diagram merupakan rancangan proses bisnis dimana setiap urutan aktivitas yang digambar merupakan proses bisnis sistem yang didefinisikan. Gambar 2 adalah activity diagram untuk aplikasi yang dirancang.

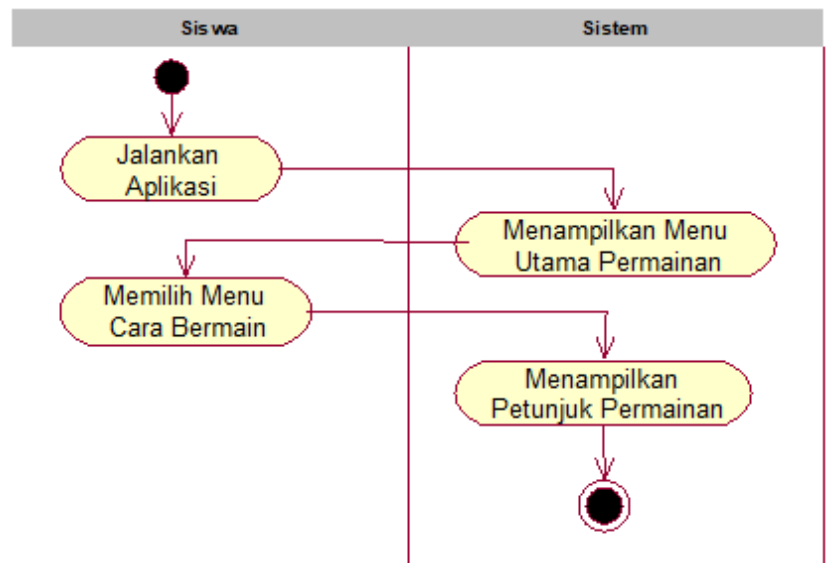

Gambar 2. Activity Diagram Menu Cara Bermain.

Siswa pertama kali menjalankan aplikasi permainan edukasi "Berhitung dengan Binatang". Saat siswa memilih menu cara bermain, sistem akan menampilkan petunjuk cara barmain dari tahap awal saat ada di menu utama sampai tahap terakhir yaitu permainan selesai.

Pada petunjuk yang ditampilkan hanya berupa gambar yang sudah diberi petunjuk berupa tanda pada setiap menu yang ditunjukan sebagai langkah-langkah untuk memainkan permainan.

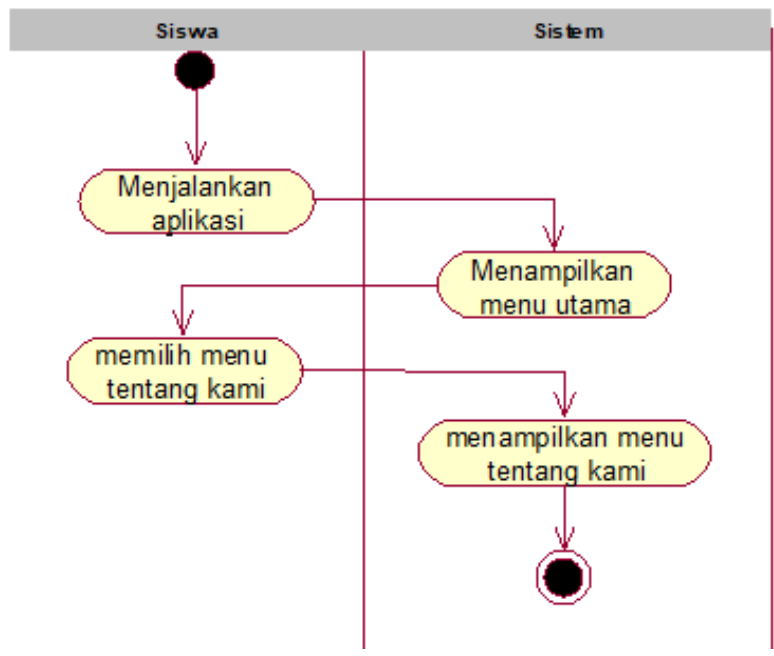

Gambar 3. Activity Diagram Menu Tentang Kami.

Pada Gambar 3 ditampilkan activity diagram saat siswa menjalankan aplikasi dan sistem akan menampilkan menu utama. Ketika siswa memilih menu tentang kami dan nemekan tombol menu tentang kami, maka sistem menampilkan informasi tentang siapa saja yang berperan dalam pembuatan pada aplikasi permainan tersebut.

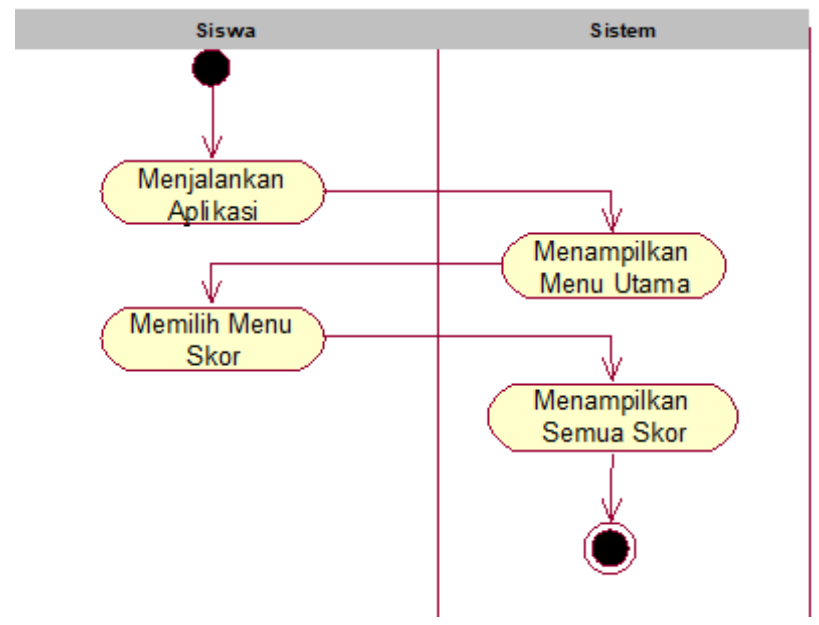

Gambar 4. Activity Diagram Menu Skor.

Pada Gambar 4 ditampilkan activity diagram saat siswa ingin memilih menu skor dan menekan tombol menu skor, sistem menampilkan jumlah bintang yang telah didapat pada permainan yang sudah dimainkan. Untuk perhitungan skor, setiap permainan minimal medapatkan 1 bintang dan maksimal mendapatkan 3 bintang. Untuk mendapatkan 3 bintang harus menyelesaikan semua soal yang ada di setiap permainan. Jika siswa hanya mendapatkan 2 bintang, maka siswa dapat melanjutkan ke level berikutnya, tetapi siswa tidak dapat melihat gambar dan informasi hewan pada permainan sebelumnya. 


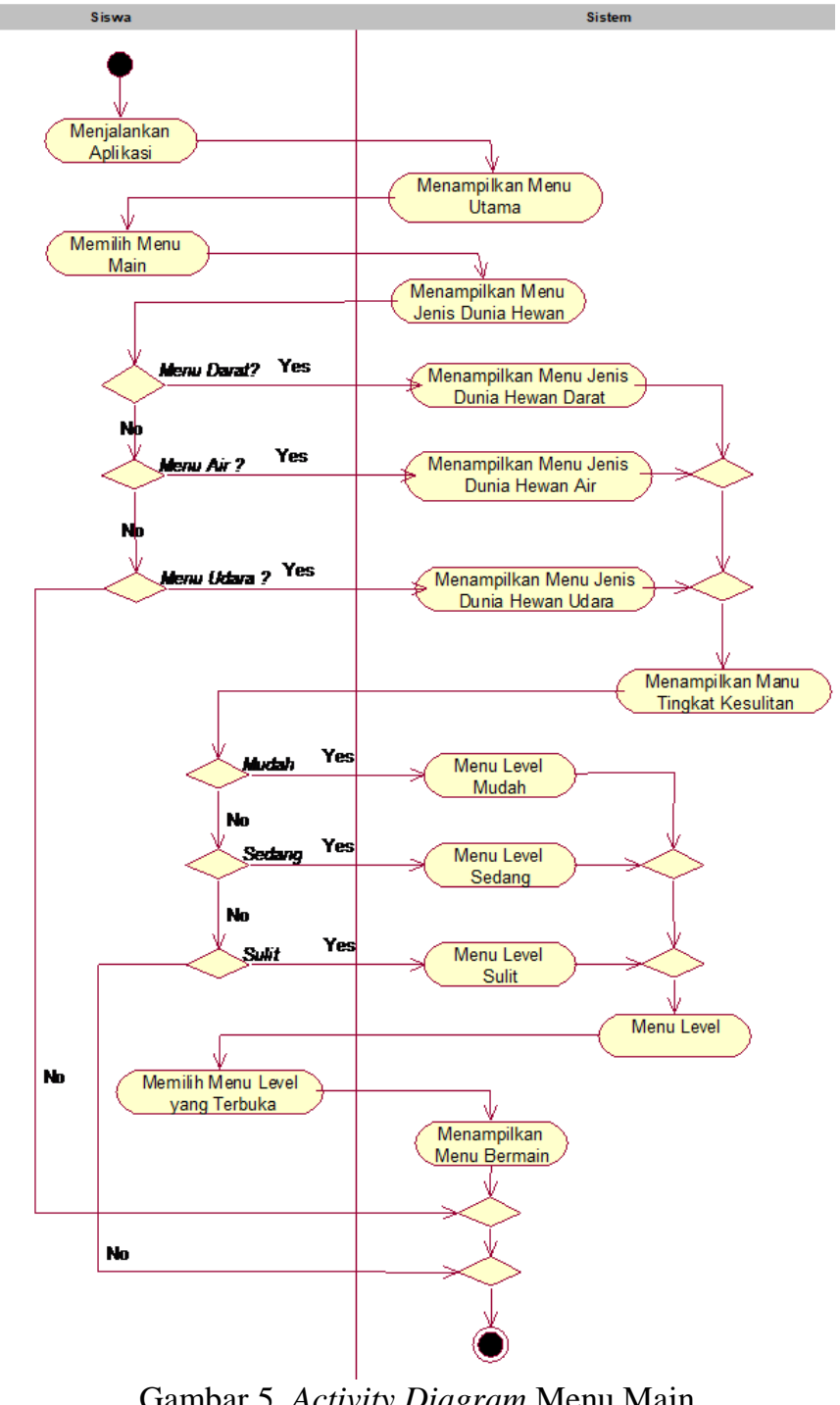

Gambar 5. Activity Diagram Menu Main

Pada Gambar 5 ditampilkan activity diagram saat sistem menampilkan menu utama, siswa memilih menu mulai agar bisa memainkan aplikasinya. Setelah siswa memilih menu mulai, sistem menampilkan menu jenis dunia hewan dan terdapat 3 menu yang disediakan yaitu dunia darat, dunia air, dan dunia udara. Untuk awal permainan, siswa hanya bisa memilih menu jenis dunia hewan darat. Setelah siswa memilih menu jenis dunia hewan darat, sistem menampilkan menu tingkat kesulitan dan terdapat 3 menu yang disediakan yaitu menu mudah, sedang, dan sulit. Untuk awal permainan, siswa hanya dapat memilih menu tingkat kesulitan mudah dan siswa harus menyelesaikan semua permainan di menu tingkat kesulitan mudah jika ingin memilih tingkat kesulitan selanjutnya.

Ketika memilih menu tingkat kesulitan mudah, sistem menampilkan menu level yang tersedia dan siswa hanya bisa memilih menu level yang terbuka. Ketika siswa memilih menu level yang terbuka, terdapat informasi dan gambar hewan yang belum terlihat jelas. Jika siswa ingin melihat informasi dan gambar hewan secara jelas, maka siswa harus menyelesaikan permainan atau harus mendapatkan tiga bintang pada permainan.

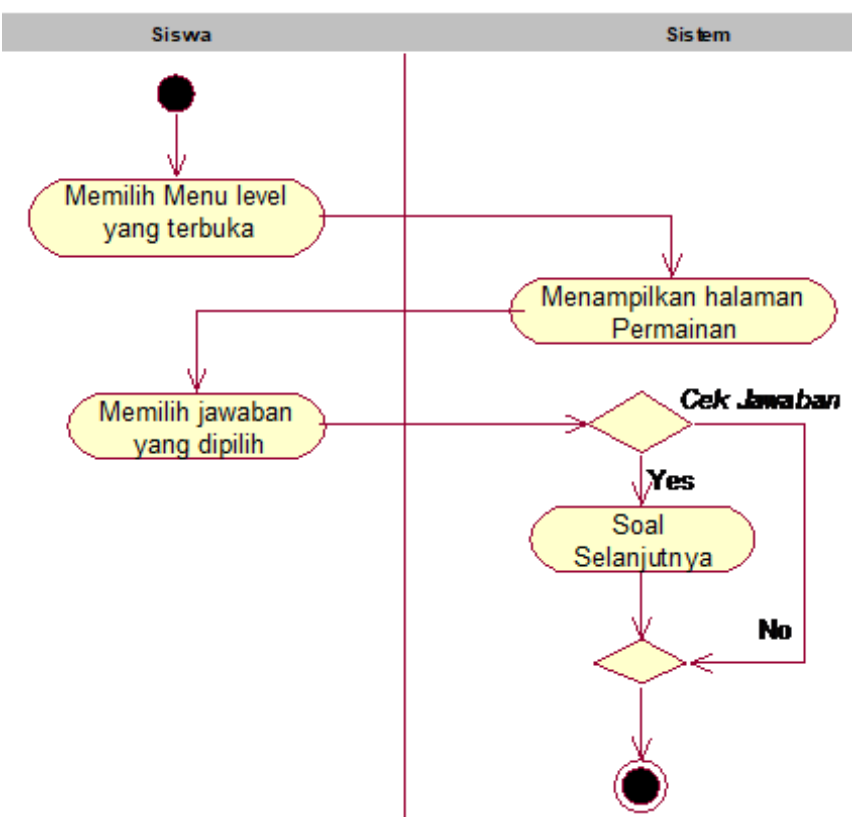

Gambar 6. Activity Diagram Halaman Permainan.

Pada Gambar 6 ditampilkan activity diagram saat siswa sudah memilih menu level yang disediakan, sistem menampilkan halaman permainan. Pada saat permainan dimulai, sistem menampilkan gambar hewan yang belum terlihat jelas dan soal Matematika beserta jawaban yang bisa dipilih. Selanjutnya siswa diminta untuk menjawab soal Matematika dengan cara memilih jawaban yang telah disediakan dan jika siswa memilih jawaban yang salah maka sistem akan menguruangi waktu selama 3 detik sampai siswa dapat memilih jawaban dengan benar. Jika siswa menjawab pertanyaan dengan benar, maka sistem memberikan notifikasi dan ada penambahan waktu selama 5 detik serta gambar hewan akan terlihat beberapa bagian. Setelah itu sistem akan menampilkan soal selanjutnya sampai gambar hewan terlihat jelas seutuhnya.

\section{Sequence Diagram}

Sequence diagram merupakan gambaran interaksi antara objek dalam urutan yang bertahap dalam interaksi tersebut sehingga dapat dijelaskan bagaimana objek-objek tersebut terhubung dan saling berinterkasi. Sequence diagram merupakan aktivitas saat pengguna berinteraksi dengan aplikasi dan bagaimana respon pengguna dalam menjalankan aplikasi tersebut. Berikut ini sequence diagram untuk aplikasi yang dirancang: 


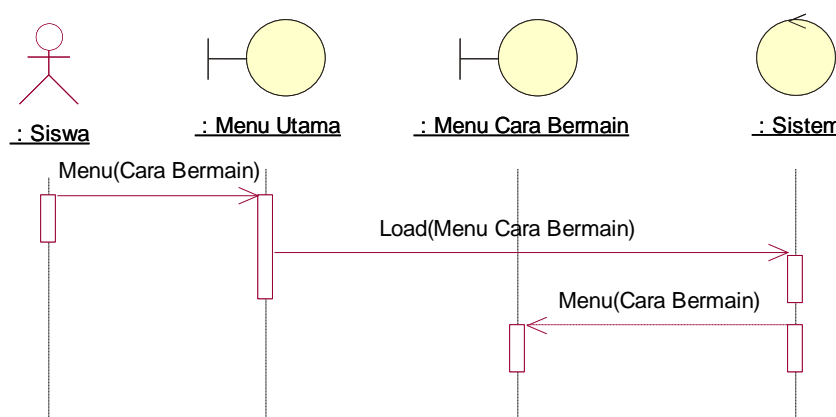

Gambar 7. Sequence Diagram Memilih Menu Cara Bermain.

Gambar 7 adalah sequence diagram yang mendeskripsikan saat siswa memilih menu cara bermain. Saat siswa memilih menu cara bermain, sistem akan menampilkan petunjuk untuk cara barmain dari tahap awal saat ada dimenu utama sampai tahap terakhir yaitu saat permainan selesai.

Pada petunjuk yang ditampilkan hanya berupa gambar yang sudah diberi petunjuk berupa tanda pada setiap menu yang ditunjukan sebagai langkah-langkah untuk memainkan permainan.

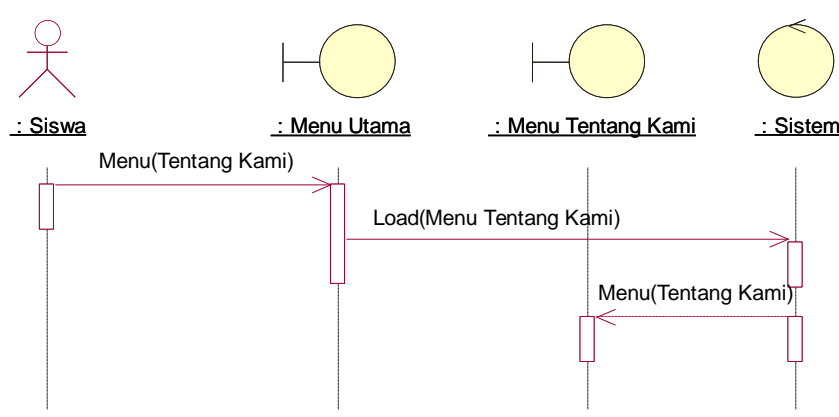

Gambar 8. Sequence Diagram Memilih Menu Tentang Kami.

Gambar 8 adalah sequence diagram yang mendeskripsikan saat siswa ingin melihat informasi tentang siapa saja yang terlibat dalam pembuatan aplikasi. Saat sistem menampilkan menu utama, siswa menekan tombol menu tentang kami. Kemudian sistem menampilkan menu yang berisi informasi tentang siapa saja yang terlibat dalam pembuatan permainan edukasi tersebut.

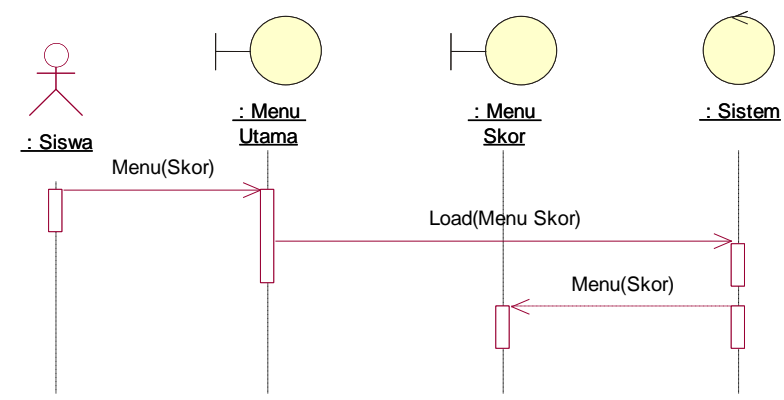

Gambar 9. Sequence Diagram Memilih Menu Skor.
Gambar 9 adalah sequence diagram yang menjelaskan saat siswa ingin melihat skor yang didapat setelah memainkan permainan. Saat sistem menampilkan menu utama dan siswa menekan menu skor, sistem akan menampilkan gambar bintang dan menapilkan jumlah yang didapat sekarang.

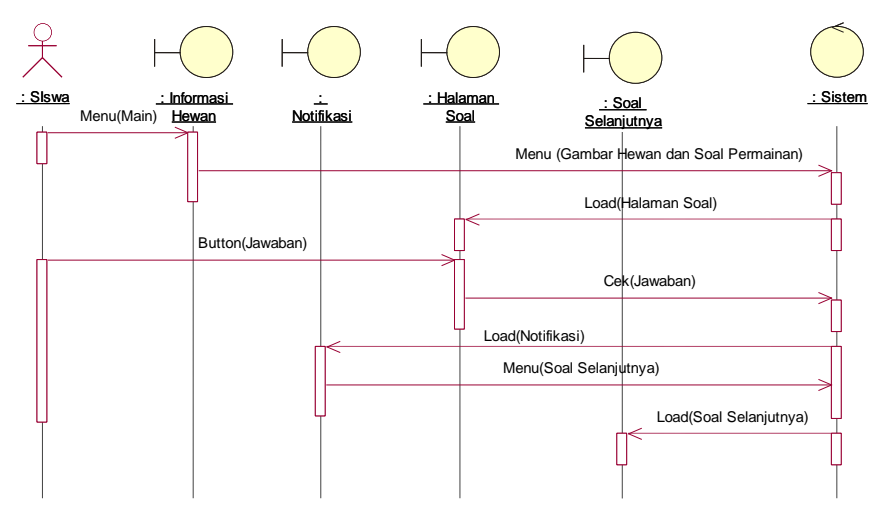

Gambar 10. Sequence Diagram Halaman Permainan.

Gambar 10 adalah sequence diagram yang menjelaskan saat siswa memainkan permainan. Saat siswa memilih menu main pada informasi hewan, sistem akan mengecek dan menampilkan halaman soal beserta gambar hewan. Kemudian saat siswa memilih jawaban yang telah disediakan, sistem mengecek jawaban yang telah dipilih.

Sistem menampilkan gambar hewan dan soal Matematika yang disediakan. Siswa dapat memilih jawaban yang disediakan oleh sistem dan sistem akan mengecek apakan jawaban yang dipilih benar atau salah. Jika siswa memilih jawabannya salah maka sistem akan memberikan notifikasi berupa suara yang menandakan jawaban yang dipilih itu salah dan mengurangi waktu yang diberikan selama 5 detik.

Jika siswa memilih jawaban dengan benar maka sistem memberikan notifikasi berupa suara yang menandakan jawaban yang dipilih itu benar dan menambah waktu yang diberikan selama 3 detik. Saat sistem mendapatkan jawaban yang benar, maka sistem menampikan notifikasi sekaligus menampilkan soal selanjutnya.

\section{Desain Arsitektural}

Pada desain arsitektural ini akan dijelaskan mengenai alur kerja dari permainan yang dibuat. Alur kerja ini berisi tentang interaksi yang ada pada siswa dan aplikasi dimana membutuhkan smartphone untuk menampilkan aplikasi permainan edukasi "Berhitung dengan Binatang". Alur sistem aplikasi ini dapat dilihat pada Gambar 11.

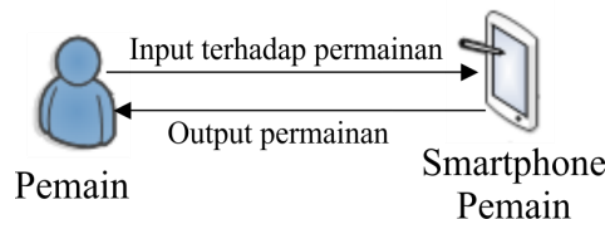

Gambar 11. Desain Arsitektural Permainan "Berhitung Dengan Binatang". 
Siswa sebagai pemain utama dalam aplikasi ini yang menggunakan smartphone untuk menjalankan dan memainkan aplikasi permainan edukasi "Berhitung dengan Binatang". Saat menjalakan aplikasi melalui smartphone, siswa hanya bisa menjalakan fitur touch screen dalam hal membuka aplikasi dan memainkan aplikasinya. Saat memainkan aplikasinya, sistem akan menapilkan gambar hewan yang belum terlihat jelas dan soal Matematika. Pada saat memainkan aplikasinya, interaksi siswa dengan smartphone terlihat lebih jelas saat siswa memilih soal dan menjawab pertanyaan yang disediakan.

\section{Desain Prosedural}

Desain prosedural perlu dibuat untuk menetapkan detail algoritma yang akan dinyatakan dalam aplikasi ini. Desain prosedural dibuat setelah menyelesaikan desain sistem, desain arsitektural, dan desain rancangan antarmuka.

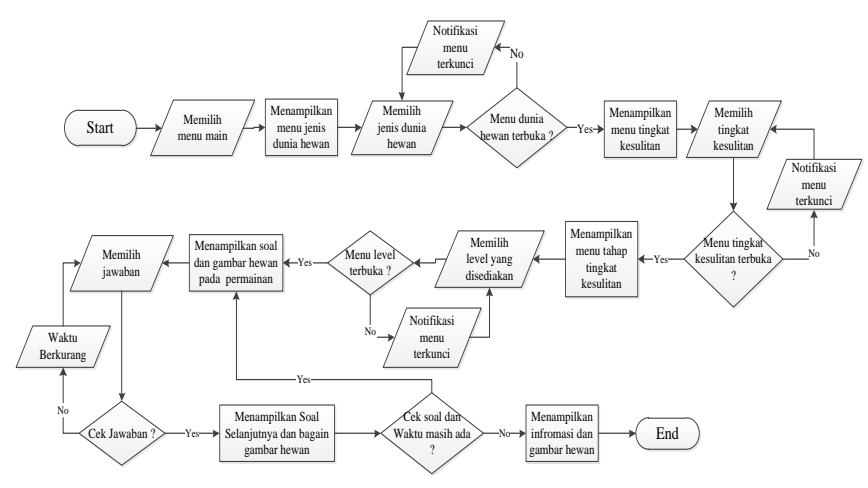

Gambar 12. Diagram Alir Proses Memulai Permainan.

Dapat dilihat pada Gambar 12 bahwa proses ini dimulai saat siswa akan memulai permainan. Pada saat siswa sudah masuk ke menu utama, siswa memilih menu main dan sistem menampilkan menu jenis dunia hewan. Terdapat 3 menu jenis dunia hewan yaitu, dunia hewan darat, dunia air, dan dunia udara. Lalu pada awal permainan, sistem hanya membuka jenis dunia hewan darat dan jika siswa memilih dunia air atau udara maka sistem menampilkan notifikasi agar siswa menyelesaikan semua permainan yang ada di menu jenis dunia darat terlebih dahulu.

Setelah siswa memilih dunia hewan darat, sistem menampilkan menu tingkat kesulitan dan terdapat 3 jenis tingkat kesulitan yaitu, tingkat kesulitan mudah, sedang, dan sulit. Untuk awal permainan, siswa hanya bisa memilih menu tingkat kesulitan mudah dan jika siswa memilih menu tingkat kesulitan sedang atau sulit, maka sistem akan menampilkan notifikasi agar siswa menyelesaikan permainan yang ada di menu tingkat kesulitan mudah terlebih dahulu.

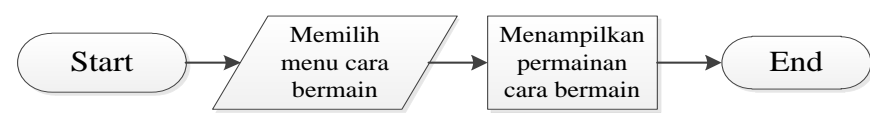

Gambar 13. Diagram Alir Proses Melihat Informasi Permainan.
Pada Gambar 13, siswa ingin mecoba aplikasi permainan edukasi "Berhitung dengan Binatang". Saat siswa pertama kali membuka aplikasi dan ingin mengetahui cara bermain pada permainan, sistem menyediakan menu cara bermain pada aplikasi agar siswa dapat memahami alur permainan. Setelah siswa memilih menu cara bermain, sistem menampilkan petunjuk dari setiap scene agar siswa dapat memainkan permainan tersebut.

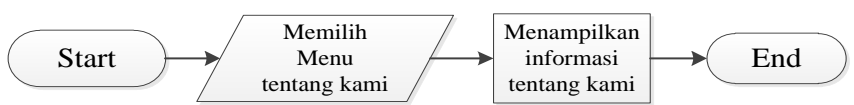

Gambar 14. Diagram Alir Proses Melihat Identitas Permainan.

Gambar 14, sistem menyediakan menu tentang kami agar siswa mengetahui informasi tentang siapa saja yang terlibat pada aplikasi permainan eduaksi "Berhitung dengan Binatang". Setelah siswa memilih menu tentang kami, sistem menampilkan nama dan desainer yang terlibat pada aplikasi.

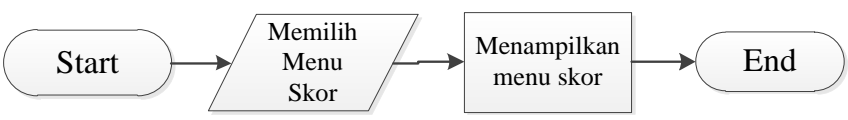

Gambar 15. Diagram Alir Proses Melihat Informasi Skor.

Gambar 15 adalahh diagram alir saat siswa ingin mengetahui jumlah bintang yang siswa dapat selama bermain. Jika siswa sudah pernah memainkan permainan, sistem akan menyimpan jumlah total bintang yang siswa dapat.

\section{Desain Antarmuka}

Berikut ini akan dijelaskan tampilan antar muka dari aplikasi "Berhitung dengan Binatang".

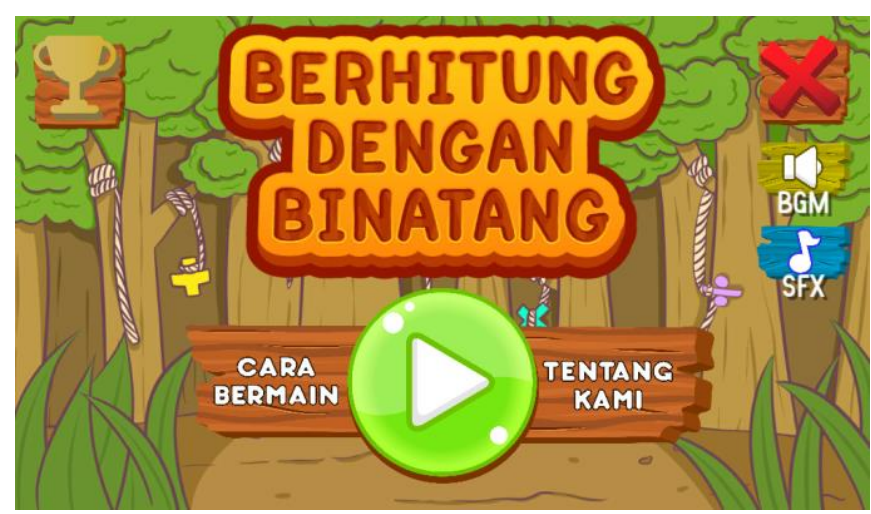

Gambar 16. Menu Utama.

Gambar 16 adalah menu utama dari permainan ini. Di dalam menu ini terdapat 6 menu yang disediakan antara lain menu main, cara bermain, tentang kami, skor, suara dan keluar. 


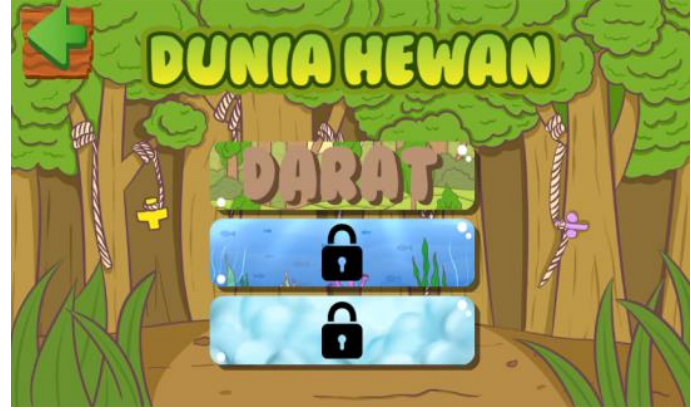

Gambar 17. Menu Dunia Hewan.

Gambar 17 merupakan menu dunia hewan yang menyediakan menu darat, air, dan udara. Pada tampilan tersebut menunjukan hanya menu darat yang terbuka dan saat pengguna memilih menu tersebut, maka sistem akan menampilkan menu tingkat kesulitan.

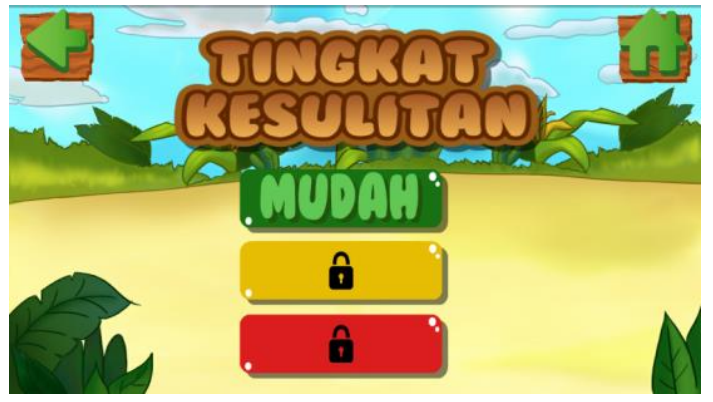

Gambar 18. Menu Tingkat Kesulitan.

Gambar 18 adalah menu tingkat kesulitan yang menyediakan menu mudah, sedang, dan sulit. Untuk awal permainan hanya menu mudah yang terbuka.

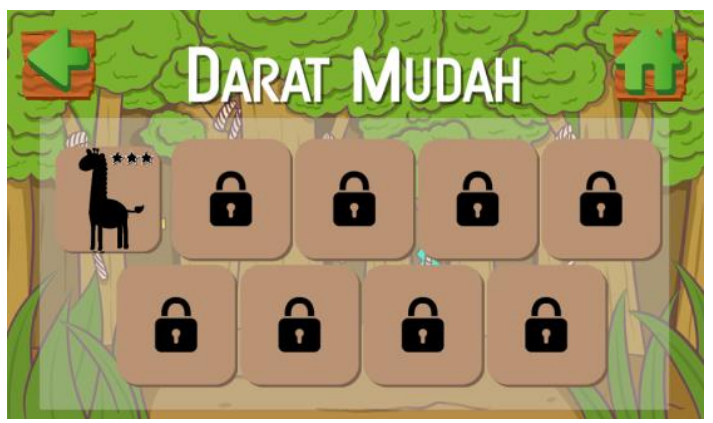

Gambar 19. Menu Level.

Gambar 19 adalah menu level yang terdapat beberapa konten hewan dengan kondisi yang terbuka dan terkunci. Untuk konten hewan yang terbuka terdapat gambar hewan dan skor bintang yang masih belum terlihat jelas. Sedangkan konten hewan yang tertutup terdapat gambar konten yang terkunci.

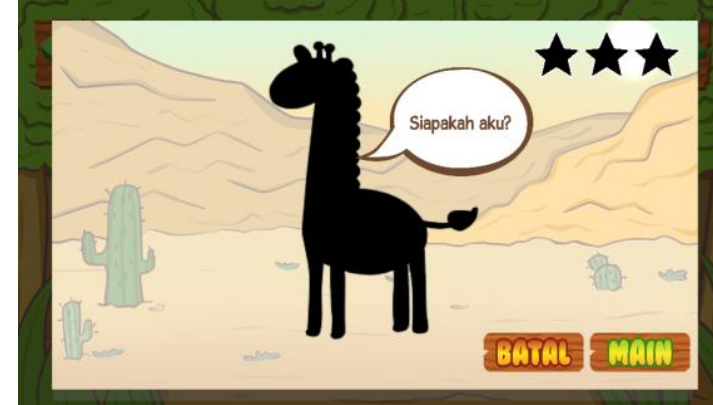

Gambar 20. Tampilan Awal Informasi dan Gambar Hewan.

Gambar 20 adalah tampilan awal informasi dan gambar hewan sebelum memulai permainan. Terdapat tombol main untuk memulai permainan dan tombol batal untuk kembali ke menu level.

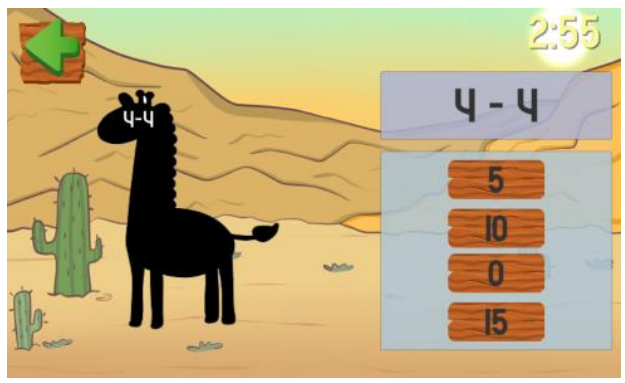

Gambar 21. Halaman Awal Permainan.

Gambar 21 saat pengguna memilih menu main, sistem menampilkan halaman awal permainan. Pada halaman tersebut terdapat gambar hewan beserta soal dan jawaban yang disediakan oleh sistem.

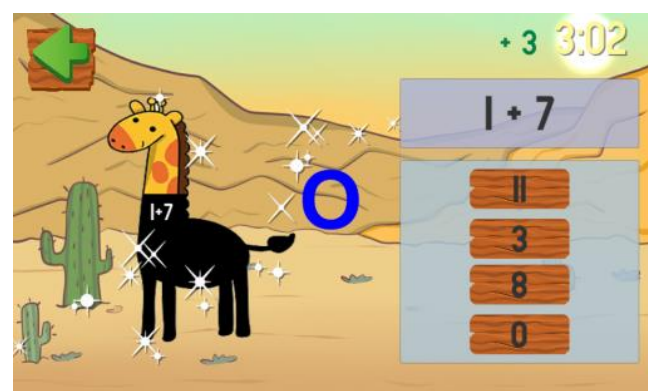

Gambar 22. Halaman Saat Kondisi Memilih Jawaban Dengan Benar.

Gambar 22 menunjukan saat pengguna memilih jawaban yang disediakan dengan benar, maka sistem akan memberikan waktu tambahan selama 3 detik dan menampilkan beberapa bagian hewan dengan jelas. Jika jawaban yang dipilih tenyata salah, maka sistem akan memberikan notifikasi dan tetap menampilkan soal dan jawaban yang sama serta mengurangi waktu selama 5 detik. 


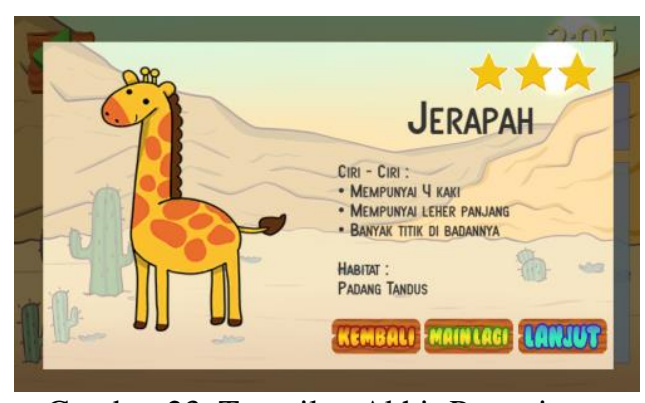

Gambar 23. Tampilan Akhir Permainan.

Gambar 23. menunjukan saat pengguna menyelesaikan semua soal yang diberikan dengan benar dan tidak ada jawaban yang salah, maka sistem akan menampilkan informasi hewan dan mendapatkan 3 bintang. Terdapat suara hewan saat gambar hewan disentuh dan dapat melanjutkan permainan.

\section{Pengujian}

Uji coba yang dilakukan pada aplikasi "Berhitung dengan Binatang" ini dengan menggunakan 3 tipe metode usability testing, Metode tersebut yaitu evaluating navigation and information architecture, evaluating the impact of subtle changers, dan comparing products. Metode pertama yang digunakan yaitu evaluating navigation and information architecture. Menurut Tom Tullis (2013) metode tersebut merupakan pengujian antara pengguna dengan fitur aplikasi yang disediakan [6]. Penelitian ini menggunakan metode tersebut bertujuan untuk menguji respon siswa Sekolah Dasar dalam menggunakan semua navigasi pada aplikasi "Berhitung dengan Binatang". Setelah pengujian, penulis melakukan perhitungan persentase dari jumlah siswa yang berhasil dalam menggunakan navigasi pada aplikasi "Berhitung dengan Binatang".

Metode kedua yang digunakan yaitu evaluating the impact of subtle changers. Menurut Jeff Sauro (2016) metode tersebut merupakan pengujian yang melibatkan beberapa kategori dalam pengujiannya [7]. kategori tersebut melibatkan beberapa aspek dan penulis memilih aspek soal Matematika dalam pengujiannya. Penulis menggunakan dua kategori dalam pengujian untuk siswa Sekolah Dasar. Kategori tersebut yaitu siswa mengerjakan soal Matematika uraian dan siswa mengerjakan soal Matematika dengan menggunakan aplikasi "Berhitung dengan Binatang". Pengujian ini bertujuan untuk mengukur ketertarikan siswa dalam mengerjakan soal Matematika dengan kategori yang berbeda. Setelah pengujian, penulis akan mengambil kesimpulan dari waktu rata - rata setiap pengguna dalam menyelesaikan semua soal yang telah diberikan, sehingga waktu dari kedua kategori tersebut dapat mengukur ketertarikan siswa dalam mengerjakan soal.

Metode ketiga yang digunakan yaitu comparing products. Menurut Jeff Sauro (2016) metode tersebut merupakan pengujian dengan melakukan perbandingan antara produk yang kita miliki dan produk yang lain [7]. Penulis menggunakan metode ini untuk membandingkan aplikasi "Berhitung dengan Binatang", "Math Games" dan "Brain Wars" sekaligus memberikan kuisioner dari ketiga aplikasi untuk mengetahui kelebihan dan kekurangan aplikasi tersebut kepada 10 pengguna orang dewasa. Pengujian ini bertujuan untuk membandingkan dan menentukan aplikasi permainan edukasi yang lebih baik bagi siswa kelas 1 sampai 3 Sekolah Dasar. Setelah pengujian, penulis melakukan perhitungan persentase dari kuisioner tersebut agar dapat mengetahui apakah salah satu aplikasi tersebut dapat dijadikan media pembelajaran untuk kelas 1-3 Sekolah Dasar.

\section{KESIMPULAN DAN SARAN}

Berdasarkan hasil uji coba yang telah dilakukan dapat diperoleh beberapa kesimpulan. Dengan menggunakan program aplikasi Unity dan metode pengembangan perangkat lunak throw-away prototyping, pembuatan aplikasi "Berhitung dengan Binatang" dapat dilakukan dengan lebih mudah.

Adanya fitur soal Matematika dan informasi sekaligus gambar hewan pada aplikasi "Berhitung dengan Binatang" dapat membantu siswa kelas 1 sampai 3 Sekolah Dasar untuk lebih tertarik pada pelajaran Matematika dan meningkatkan wawasan serta pengetahuan dengan mengetahui berbagai jenis hewan.

Aplikasi "Berhitung dengan Binatang" mudah dioperasikan oleh siswa. Hal ini dapat dibuktikan dari hasil pengujian dengan metode navigation and information architecture yang menunjukan bahwa $82 \%$ dari sistem navigasi pada aplikasi "Berhitung dengan Binatang" telah dipahami oleh siswa kelas 1 sampai 3 Sekolah Dasar.

Anak-anak lebih tertarik untuk menyelesaikan soal Matematika dalam wujud aplikasi dibanding dengan soal Matematika uraian. Hal ini dapat dibuktikan hasil pengujian dengan metode evaluating the impact of subtle changes yang menunjukan bahwa siswa kelas 1 sampai 3 Sekolah Dasar hanya membutuhkan waktu rata-rata 2 menit untuk menyelesaikan 5 level pada permainan (23 soal Matematika) dibanding dengan menyelesaikan 20 soal Matematika uraian dengan waktu rata-rata 8 menit.

Aplikasi "Berhitung dengan Binatang" cocok digunakan sebagai media edukasi bagi anak-anak. Hal ini dapat dibuktikan dari hasil pengujian metode comparing products dimana dapat disimpulkan bahwa $73 \%$ dari sepuluh pengguna orang dewasa lebih setuju menggunakan aplikasi "Berhitung dengan Binatang" sebagai aplikasi permainan edukasi bagi siswa kelas 1 sampai 3 Sekolah Dasar dibandingkan dengan "Math Games" dan "Brain Wars".

Berdasarkan hasil uji coba yang telah dilakukan dapat diperoleh beberapa saran. Saran-saran yang bermanfaat dan membangun adalah sebagai berikut:

1. Adanya pengenalan lebih dalam tentang informasi hewan seperti jenis makanannya dan bagaimana cara berkembang biak.

2. Memperbanyak jumlah tingkat kesulitan permainan dan menambahkan variasi hewan agar anak-anak dapat mengenal berbagai macam jenis hewan lainnya. 
3. Menambah animasi pada setiap hewan agar anak-anak dapat mengenal tingkah laku berbagai macam hewan.

4. Penambahan soal Matematika lebih dari dua operand sehingga dapat meningkatkan kemampuan hitung anakanak.

\section{REFERENSI}

[1] Jufri, W. (2017). Belajar dan Pembelajaran Sains: Modal Dasar Menjadi Guru Profesional. Bandung: Pustaka Reka Cipta.

[2] Rountree, W.L. (2015). Redesigning Traditional Children's Games to Teach Number Sense and Reinforce Measurement Estimation Skills Using Wearable Technology. Arkansas: Worcester Polytechnic Institute.

[3] Hamzah, A. (2014). Perencanaan dan Strategi Pembelajaran Matematika. Jakarta: Rajawali Pers.

[4] Widoyoko, E.P. (2016). Evaluasi Program Pembelajaran Panduan Praktis bagi Pendidik dan Calon Pendidik. Yogyakarta: Pustaka Pelajar.

[5] Enterprise, J. (2017). Mengenal Pemrograman Komputer dan Android untuk Pemula. Jakarta: PT Elex Media Komputindo.

[6] Tullis, T. \& Alberrt, B. (2013). Meansuring the User Experience: Collecting, Analyzing, and Presenting Usability Metrics. United States America: Morgan Kaufmann.

[7] Sauro, J. \& Lewis, R.J. (2016). Quantifying the User Experience: Pratical Statistics for User Research. United States America: Morgan Kaufmann. 